Hena Maes-Jelinek, "Prologue and Acknowledgements", in A Talent(ed) Digger: Creations, Cameos, and Essays in Honour of Anna Rutherford, ed. Hena Maes-Jelinek, Gordon Collier \& Geoffrey V. Davis (Amsterdam \& Atlanta: Rodopi, 1996), pp. xvxviii.

\section{PROLOGUE AND ACKNOWLEDGEMENTS}

Dear Anna,

When I first met you in the corridor of a dormitory on the campus of the University of Queensland in 1968 - the year of many a cultural revolution - I little suspected how much this meeting would affect my research, my teaching, sometimes my way of life and the friendships I made through you. We were attending the second international ACLALS conference, the first for both of us and, for both, I think, a determining factor in our subsequent activities and career. I had begun a few years before to explore the fiction of "Commonwealth" writers. But what I remember most vividly from this conference is the sense of excitement at discovering new modes of writing, new ways of perceiving other worlds, and the enthusiasm awakened in me for original poets and novelists, then mostly unknown in Europe and certainly uncanonized, who were bringing a new authenticity their authenticity - to literature. It was also in Brisbane that I first heard Wilson Harris speak, and where I decided to re-read the Guyana Quartet and further explore his work. In the autumn of 1969 , when we were in London together, it was you who decided that, since I was interested in his fiction and had begun to write on it, we should visit him; for I would never then have dared phone a writer, least of all one I greatly admired. Our conversation that evening with Wilson, Margaret, and John La Rose, also present, marked the beginning of my lasting interest in Wilson Harris's work and in West Indian literature, further stimulated by our trip around the Caribbean and our encounter with its landscapes and people after the third ACLALS conference, held in Jamaica. You have since then remained indelibly associated with the wonder and exhilaration I experienced in those early years, while your infectious though unmatchable energy spurred me on to initiatives of my own in Commonwealth studies.

When we returned from the ACLALS conference in the West Indies in 1971, you had the idea of founding a regional association (the first of its kind) and organized the first EACLALS conference that very spring in an Aarhus still under snow. The University of Aarhus subsequently became the first centre for Commonwealth studies on the European continent and the first to offer there the full spectrum of courses in Commonwealth literature (some of them compulsory, on a par with English and American literature) - al this at a time when Commonwealth studies were unheard of in Britain and the rest of the 
Commonwealth save for the groundbreaking work done by Derry Jeffares at Leeds. Writers and critics in post-colonial literatures from all over the world began to visit the University of Aarhus at your invitation, most of them enjoying the hospitality of Pinds Hus, provided they were willing to cook for themselves.

It was also in 1971 that the first Commonwealth Newsletter came out. By the end of the decade, in 1979. you had transformed it into Kunapipi, an international arts magazine which, through the years, has remained faithful to its initial purpose: to introduce "the work of new or little known writers of talent and to provide critical evaluation of the work of living authors, both famous and unknown." This has also been the policy behind Dangaroo Press, which you created in 1975 after Wilson Harris's visit to Aarhus because you thought the substance of his seminars ought to be published; which you then did, in Enigma of Values. Dangaroo's now impressive list of published books includes collections of poetry, short stories, essays, and critical studies which not only trace the development of post-colonial criticism (After Europe, From Commontvealth to Post-Colonial, Decolonising Fictions) but also signal your commitment to those who at one stage or another experienced or suffered the consequences of any form of colonization (A Double Colonization: Colonial and Post-Colonial Women's Writing, Displaced Persons, Aboriginal Culture Today, Unbecoming Daughters of the Empire, Into the Nineties). There have also been art books, combining poetry and photos (Malin, Hebrides, Minches), an illustrated commentary on Hogarth's Blacks, a collection of African writing and designs (Covries and Kobos), and the beautiful Guyana Dreaming, on Aubrey Williams's paintings. The covers of these books and of Kunapipi, sometimes paintings or engravings of your favourite artists but all conceived by yourself, must have made more than one professional designer envious. For years you have run the press singlehanded or with very little assistance, and one cannot help wondering at the variety of your talents, the eclecticism of your interests, and the openness with which you have promoted artists who might otherwise have remained unknown outside their own geographical area.

Such a record of creative activities in addition to full-time lecturing, however, would evoke a misleading picture of you if I didn't also recall that our meetings were usually a mixture of hard work and fun - as when, after a tiring session of editorial work, you and René (equally bad at foreign languages) would tell each other jokes in broken English or French and go off into peals of laughter while my bilingual self was trying to make it all out. And always you instilled in your friends the sense that whatever they were involved in, whether work, reading a writer you had just "discovered," or taking up challenges just for fun, was exciting and worth doing - especially when you drove nearly a thousand kilometres from Aarhus to Liège with a few students, only to make them taste "the best chips in the world" and drive back again after a few hours. Or like that time in Nigeria, when you thought René and I should see the big market at Talata Mafara, and you drove six hundred kilometres to take us there ....

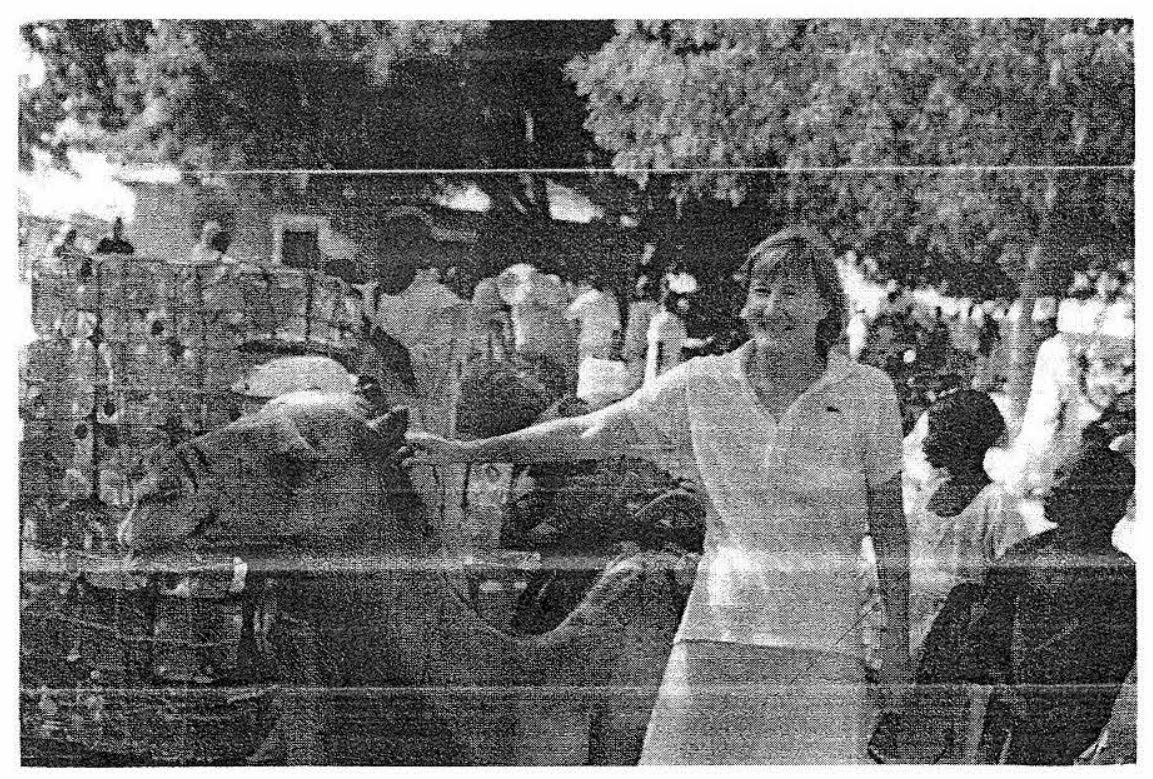

\section{A nna at Talata Mafara market, Nigeria, 1976}

It is this inimitable blend in you of high seriousness (when you "mean business"), sense of humour, love of fun, and generous support of other people's work that drew an overwhelmingly positive response from writers and scholars worldwide when a circular inviting contributions to this volume was sent out. Some contributors, who hadn't been approached in the first place but heard of our venture, asked to be allowed to join an this tribute to you. All expressed a similar admiration for the leading role you have played in the post-colonial field through your work and your personality. Many recalled their gratitude for the encouragement they had received from you at one time or another, or for the publication of their work because you believed in it and not for financial profit.

The contributions to this volume are an homage from writers and critics, who were pleased to have this opportunity to express their friendship and acknowledgement of your many talents. Gerry Turcotte writes that before he met you, you seemed a legendary and formidable figure of whom he was secretly terrified; but he was immediately won over by your generosity, directness, and purposefulness when he first met you. Bernth Lindfors emphasizes the multifariousness of your renown as a scholar, editor, publisher, teacher, conference organizer, ACLALS administrator, photographer, and designer. Derry Jeffares pinpoints your zest, your "indomitable ability to sense what matters," your drive and energy. Wilson Harris says: "Anna is a child of contradictory forces born of precipitations 
of energy from the Pacific into the Atlantic and vice-versa. One is aware of such energies placed and displaced, ordered and disordered, in Hal Porter's The Tilted Cross, Patrick White's later novels. Randolph Stow's Luciferian achievement in Tourmaline's paradise lost. The drive of such energy is remarkable."

Throughout your career, you have shown an unflinching - indeed, a stubborn determination (the indomitable Irish in you?) to meet self-imposed challenges. You are often impatient. and your highest praise of an interlocutor is to say (s)he is "sharp." Over the years we have become familiar with your untamable enthusiasm, persuasiveness, courage, and a self-assurance which can be daunting to others. But the warmth and fidelity of your friendship are unshakeable, and there is a frailer, more vulnerable self in you which will dart through the chinks in your armour and remind your relieved friends that you are not a superwoman after all but as fully human as they are.

No doubt your experiences as a younger woman saved you from becoming a conventional academic. You have been a primary-school teacher in Canada and in London, a P.E. teacher, and, having made the highest grade in music (A MUS A), you were head of the music department at a secondary school in your beloved Newcastle. At some stage, I remember, it was as important to you to be a competition squash player, a first-rate tennis player, swimmer and surfer, and a qualified life-saver on Australia's famous beaches as it was to be a qualified academic

Many years ago, you sent me a little notebook with a cover you had embroidered yourself in Danish points de croix. enclosing the comment "a labour of love." I believe that all those who have participated in this volume have done so in the same spirit, in friendship and in thankfulness.

Your "dear, kind, Loving friend,"

\section{Hena}

Christmas 1995

PS: Others, too, have in different ways shown their appreciation for you and your signal endeavour. $A R$ Thanks for their generous financial support are due to the Literature Board of the Australia Council and to Euregio (an organization devoted to regional cooperation between Belgium. Germany and Holland). $\approx$ \& to use, for the cover, prints by Barbara Hanrahan, your favourite Australian artist, as many Kunapipi covers and Dangaroo books show. $\$ R \propto I$ I personally wish to express my warmest thanks to Gordon Collier, without whose dedication, high competence, editorial and text production skills this book would not have been ready to celebrate your achievement on the occasion of the EACLALS Jubilee.

Hena MaEs-JelineK 